Check for updates

Cite this: Chem. Sci., 2019, 10, 7049

๑ All publication charges for this article have been paid for by the Royal Society of Chemistry

\section{Structure of formylglycine-generating enzyme in complex with copper and a substrate reveals an acidic pocket for binding and activation of molecular oxygen $\dagger$}

\author{
Dzmitry A. Miarzlou, (D) Florian Leisinger, (D) Daniel Joss, (D) Daniel Häussinger (D) \\ and Florian P. Seebeck (D) *
}

The formylglycine generating enzyme (FGE) catalyzes oxidative conversion of specific peptidyl-cysteine residues to formylglycine. FGE mediates $\mathrm{O}_{2}$-activation and hydrogen-atom abstraction in an active site that contains $\mathrm{Cu}(\mathrm{l})$ coordinated to two cysteine residues. Similar coordination geometries are common among copper-sensing transcription factors and copper-chaperone but are unprecedented among copper-dependent oxidases. To examine the mechanism of this unusual catalyst we determined the 1.04 $\AA$ structure of FGE from Thermomonospora curvata in complex with copper and a cysteine-containing peptide substrate. This structure unveils a network of four crystallographic waters and two active site residues that form a highly acidic $\mathrm{O}_{2}$-binding pocket juxtaposed to the trigonal planar tris-cysteine coordinated $\mathrm{Cu}\left({ }_{1}\right)$ center. Comparison with structures of FGE in complex with $\mathrm{Ag}\left({ }^{\prime}\right)$ and $\mathrm{Cd}(॥)$ combined with evidence from NMR spectroscopy and kinetic observations highlight several structural changes that are induced by substrate binding and prime the enzyme for $\mathrm{O}_{2}$-binding and subsequent activation.
Received 8th April 2019

Accepted 11th June 2019

DOI: $10.1039 /$ c9sc01723b

rsc.li/chemical-science order to examine specific aspects of copper-catalysis, but also with an eye on application in organic synthesis., ${ }^{2,13}$ Not surprisingly, most of these compounds also contain nitrogenrich ligand sets.

The mononuclear copper proteins of the second group do not necessarily catalyze reactions but rather contribute to cellular copper-transport and sensing. Representative examples are the Cu-responsive transcriptional activator CueR, ${ }^{14}$ and the copper chaperone Atox $1 .^{15}$ These proteins bind $\mathrm{Cu}(\mathrm{I})$ in a linear bis-cysteine coordination sphere with extremely high affinity. ${ }^{16}$ This coordination-type provides an ideal solution to form redox inert protein:copper complexes with maximal thermodynamic stability, while enabling reversible transfer of $\mathrm{Cu}(\mathrm{I})$ from one protein to another. ${ }^{15,17}$

The formylglycine generating enzyme (FGE) is unique, since it cannot be attributed to either the first or the second group of copper-binding proteins. FGE binds a single $\mathrm{Cu}(\mathrm{I})$ by linear biscysteine coordination and catalyzes copper-dependent $\mathrm{O}_{2}$ activation. ${ }^{18,19}$ FGE catalyzes the oxidative conversion of specific peptidyl-cysteines to formylglycine via abstraction of the pro(R)- $\beta$-hydrogen atom (fGly, Fig. 1). This posttranslational modification is important for sulfatases which use the hydrated form of fGly as catalytic nucleophile. ${ }^{20}$ FGE has attracted scientific interest for several reasons. Initially, this enzyme was discovered in the pursuit of finding the molecular cause for the storage disease multiple sulfatase deficiency. ${ }^{20,21}$ The subsequent realization that FGE can be used as a tool to introduce
Department of Chemistry, University of Basel, Mattenstrasse 24a, Basel 4002, Switzerland. E-mail: florian.seebeck@unibas.ch; Tel: +41612071143

$\dagger$ Electronic supplementary information (ESI) available: Detailed descriptions of all experiments, supporting Fig. (S1-S15) and Tables (S1-S4) are shown in the ESI. See DOI: $10.1039 / \mathrm{c} 9 \mathrm{sc} 01723 \mathrm{~b}$ 


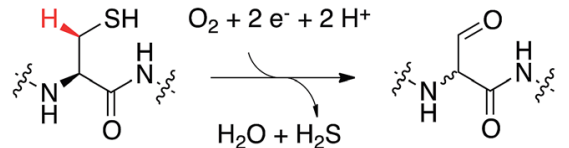

Fig. 1 FGE-catalyzed oxidation of peptidyl-cysteine to formylglycine (fGly) is initiated by abstraction of the pro- $(R)-\beta$-hydrogen atom from the substrate (red).

electrophilic aldehyde functions into recombinant proteins highlighted the considerable biotechnological potential of this enzyme. ${ }^{22-24}$ Finally, the recent discovery that FGE is a copperdependent enzyme opened the door for mechanistic studies on this unique enzyme. ${ }^{\mathbf{1 8 , 1 9 , 2 5 , 2 6}}$ The crystal structure of FGE from Thermomonospora curvata ( $t c \mathrm{FGE}$ ) in complex with $\operatorname{Ag}(\mathrm{I})$ (tcFGE_Ag, PDB: 5NXL), and most recently, the crystal structure of FGE from Streptomyces coelicolor in complex with $\mathrm{Cu}(\mathrm{I})$ (scFGE_Cu, PDB: 6MUJ), combined with biochemical characterization showed that two active site cysteines are the only metal ligands and that the $\mathrm{Cu}(\mathrm{I})$ bound state is the catalytic resting state. ${ }^{25-27}$ In this way, FGE represents an entirely new type of copper-enzyme. Structural and mechanistic studies on this enzyme may inspire new directions in the design of abiotic copper-catalysts. ${ }^{2}$ Conversely, the similarities of the primary metal coordination sphere in FGE and non-catalytic Cu-binding proteins raise the questions as to what secondary features may enable $\mathrm{O}_{2}$-activation by FGE. Identification of these features may help to identify redox enzymes, masquerading as coppertrafficking proteins, or could provide guidelines to engineer novel redox-activity into existing copper-proteins.

In this report we describe the crystal structure of $t c$ FGE in complex with $\mathrm{Cu}(\mathrm{I})$ and a 17-residue substrate analog. Based on this structure together with NMR spectroscopy and kinetic characterization, we identify an acidic $\mathrm{O}_{2}$-binding pocked juxtaposed to the copper center as key determinant for efficient $\mathrm{O}_{2}$-activation.

\section{Results and discussion}

\section{Crystallization of $t c F G E$ in complex with $\mathrm{Cu}(\mathrm{I})$ and a substrate- analog}

Recombinant $t c$ FGE was produced in Escherichia coli (see ESI $\dagger$ ). ${ }^{19}$ The purified enzyme was crystallized in the presence of 1.2 equivalents of $\mathrm{Cu}(\mathrm{I})$ and 2.8 equivalents of a synthetic 17residue substrate-analog. To stabilize the enzyme:substrate complex, crystallization and room-temperature handling of the crystals were executed under anoxic conditions. The sequence of the substrate-analog (FGE-27: Abz-ATTPLCGPSRASILSGR, $\mathrm{Abz}=o$-aminobenzoic acid) was derived from the active site segment of a putative arylsulfatase (WP_012850446) from $T$. curvata. Using isothermal titration calorimetry (ITC), we established that this peptide binds to an inactive variant of $t c \mathrm{FGE}$ $\left(t c \mathrm{FGE}_{\mathrm{W} 228 \mathrm{~F}}\right.$, see below) with a $K_{\mathrm{d}}=40 \pm 10 \mathrm{nM}$ (Fig. S2 $\dagger$ ), indicating that the wild type enzyme would also form a stable complex with this peptide. Single crystals were isolated from solutions containing purified tcFGE (21.5 $\mathrm{mg} \mathrm{mL}^{-1}$ ), $\mathrm{CuCl}$, peptide, PEG 8000 (10\%), Tris-HCl (0.1 M, pH 7.0) and $\mathrm{MgCl}_{2}$
$(0.2 \mathrm{M})$. Diffraction data could be processed up to a resolution of $1.04 \AA$ (Fig. 2A). At this resolution conservative estimates of standard deviations (r.m.s.) are $\pm 0.05 \AA$ for bond lengths and $\pm 2^{\circ}$ for bond angles. ${ }^{28}$ The unbiased electron density revealed a continuous polypeptide chain from -1 to 302 for $t c F G E$ and from Abz (-6) to Gly (11) for the substrate FGE-27. Two Ca(II) ions were identified in two conserved calcium binding sites (Fig. S3†). ${ }^{26,29,30}$ The high resolution of this data set allowed placement of 494 crystallographic waters, in particular four waters in the active site $\left(\mathrm{H}_{2} \mathrm{O} \_1-4\right)$ with high confidence (Fig. $\mathrm{S} 4 \dagger$ ). The overall structure of $t c$ FGE and its similarity to human FGE ( $h s$ FGE) and $s c$ FGE has been discussed previously. ${ }^{26,29,30}$ Therefore, the main focus here will be on the structure of the substrate binding pocket and the metal binding site. For this discussion we compare tcFGE in complex with $\mathrm{Cu}(\mathrm{I})$ and substrate ( $t c \mathrm{FGE} \_\mathrm{Cu} \_\mathrm{S}$ ) with the structure of tcFGE in complex Ag(I) (tcFGE_Ag) as a model for $t c$ FGE in complex with $\mathrm{Cu}(\mathrm{I})$ ( $t c \mathrm{FGE} \_\mathrm{Cu}$ ). The structure of $s c$ FGE in complex with $\mathrm{Cu}$ ( $s c$ FGE_Cu) has also become available very recently. ${ }^{27}$ The metal binding sites in $s c$ FGE_Cu and $t c F G E \_A g$ were found to be essentially isostructural.

\section{Position of the substrate}

The unbiased electron density for the peptide reveals ordered positions for all residues except for the C-terminal Arg10 (Fig. 2B). The residues in the N-terminal part (Ala-5-Ser4), except for Cys1, adopt extended backbone conformations $\left(\phi=-50^{\circ}\right.$ to $-136^{\circ} ; \psi=$ $\left.120-170^{\circ}\right)$. The conformation of Cys1 $\left(\phi=-108^{\circ} ; \psi=-20^{\circ}\right)$ induces a sharp turn allowing this residue to access the copper localized at the deepest point of the substrate binding pocket (Fig. 2). Pro-2 and Pro3 make extensive hydrophobic interactions with Phe38/Tyr273 and Phe86/Trp109 respectively. In contrast, Ala-5, Thr-4, Thr-3 and Leu-1 make little or no contact with the protein surface. The C-terminal residues Arg3-Ile6 adopt dihedral angles consistent with a helical conformation $(\phi=-90$ to $62 ; \psi=$ -30 to -5$)$. Indeed, the network of intramolecular backbonebackbone hydrogen bonds is reminiscent of a short $3_{10}$-helix (Fig. 2C). The side chain of Ser4 hydrogen bonds to the backbone amide of Ser7 (3.0 $)$, serving as a N-terminal helix cap. ${ }^{31}$ In return, the side chain of Ser7 hydrogen bonds with the backbone carbonyl of Ser4 (2.7 ̊). The guanidinium side chain of Arg5 makes a $\pi$-cation interaction with the indole ring of Trp84, in addition to hydrogen-bonds with Ser290 $(2.8 \AA)$, and the backbone carbonyl of Trp84 (2.9 ̊). The side chain of Ile8 binds to a hydrophobic dell lined by the side chains of Trp84, Phe86, Met99 and Ala101. The side chains of Ala6, Leu9 and the following residues (Ser10, Gly11 and Arg12) make no interaction with the protein surface. The helical structure of the substrate may be further stabilized by weak interactions with neighboring $t c F G E$ chains (Fig. 2D and E).

$h s F G E$ has been crystallized with a seven-residue substrate (LCTPSRA, $h s$ FGE_S, PDB: 2AIK). ${ }^{32}$ This structure contains no metal in the active site and Cys366 (Cys274 in tcFGE) was mutated to Ser. Instead, the substrate cysteine is linked via disulfide bond to Cys341 (Cys269 in tcFGE). Despite these damages, the equivalent substrate residues in $t c \mathrm{FGE} \_\mathrm{Cu} \_\mathrm{S}$ and 


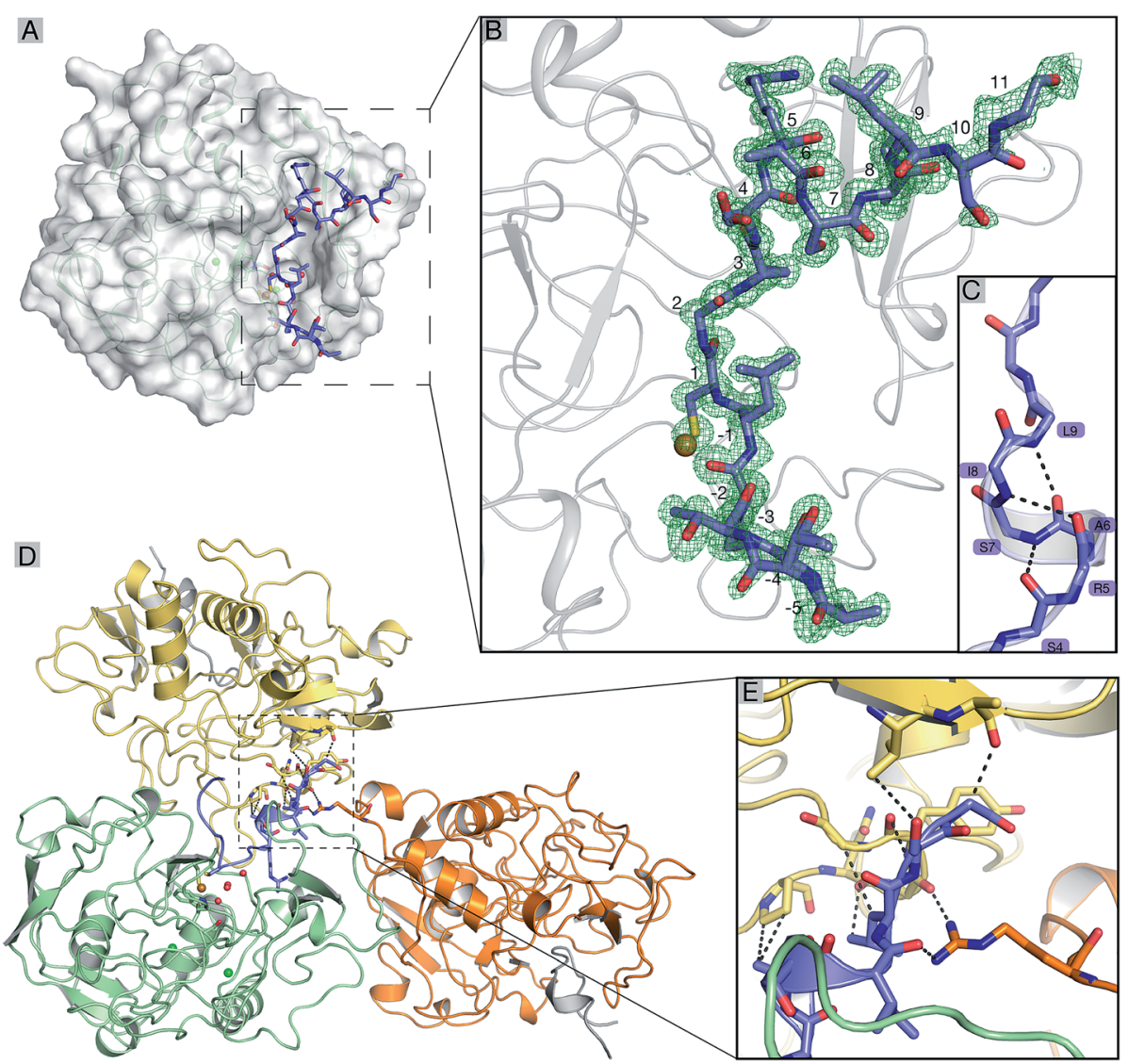

Fig. 2 (A) Structure of tcFGE in complex with $\mathrm{Cu}\left(\right.$ () and substrate (tcFGE_Cu_S). The 17-residue peptide substrate (violet). (B) The $m\left|F_{\mathrm{o}}\right|-D_{\mathrm{C}}\left|F_{\mathrm{c}}\right|$ omit map for the substrate model is contoured at $\sigma$-level $=3.0$. (C) The $C$-terminus of the substrate folds into a short $3_{10}$-helix and interacts with neighboring tcFGE chains in the crystal ( $D$ and $E$ ). The dashed lines in (E) indicate nearest contacts, not necessarily attractive interactions.

hsFGE_S adopt almost identical positions in the substrate binding pocket (Fig. S5†). Apparently, residues $0-5$, the conserved residues Pro3 and Arg5 in particular (numbering according to $t c$ FGE_Cu_S) make sufficient interactions with the substrate binding pocket to steer the targeted cysteine residue into the active site - even in the absence of $\mathrm{Cu}(\mathrm{I})$.

Indeed, the biotechnological potential of FGE depends on its ability to target cysteine residues embedded in the minimal LCXPXR motif. The limited length of this motif can be inserted into $\mathrm{N}$ - or C-termini or surface exposed loops of unrelated proteins without significant disturbance of the structure and stability of the parent protein. ${ }^{22,23,33,34}$ On the other hand, comparison of kinetic parameters from in vitro studies with 9-, 14- and 23-residue substrates showed that longer substrates are recognized with significantly higher affinity. ${ }^{18,19,35}$ The structure of $t c \mathrm{FGE}_{-} \mathrm{Cu} \_\mathrm{S}$ provides a convincing explanation for this observation. The C-terminal residues Arg5-Ile8 adopt a defined secondary structure that positions Ile8 for additional hydrophobic contact with FGE. Likewise, Pro-2 also makes a specific contact with the enzyme that has not been observed in the structure of $h s$ FGE_S. The more comprehensive picture of the enzyme:substrate interaction seen in the structure of $t c \mathrm{FGE}_{-}-$ Cu_S could provide a valuable starting point for the design of FGE variants that accept alternative motifs with applications in orthogonal bifunctionalization of recombinant proteins. ${ }^{36}$

\section{Primary and secondary coordination sphere}

The structure of FGE_Cu_S demonstrates that the peptidyl cysteine (Cys1) from the substrate is a direct ligand of the catalytic $\mathrm{Cu}(\mathrm{I})$. This finding corroborates XAS observations suggesting trigonal coordination of $\mathrm{Cu}(\mathrm{I})$ by $s c \mathrm{FGE}$ and its substrate. ${ }^{27}$ The three thiol side chains of Cys269 $\left(\mathrm{Cu}-\mathrm{S}_{\mathrm{Cys} 269}\right.$ : $2.2 \AA)$, Cys274 (Cu-S $\left.\mathrm{S}_{\mathrm{Cys} 274}: 2.3 \AA\right)$ and the Cys1 (Cu-S $\left.\mathrm{S}_{\mathrm{Cys} 1}: 2.2 \AA\right)$ coordinate $\mathrm{Cu}(\mathrm{I})$ in an irregular trigonal planar complex with significant deviations from the expected $120^{\circ} \mathrm{S}-\mathrm{Cu}-\mathrm{S}$ bond angles $\left(\mathrm{S}_{\mathrm{Cys} 269^{-}} \mathrm{Cu}-\mathrm{SC}_{\mathrm{ys} 274}: 108^{\circ} ; \mathrm{S}_{\mathrm{Cys} 274^{-}}-\mathrm{Cu}-\mathrm{S}_{\mathrm{Cys} 1}: 104^{\circ} ; \mathrm{S}_{\mathrm{Cys} 269^{-}}\right.$ $\left.\mathrm{Cu}-\mathrm{S}_{\mathrm{Cys} 1}: 147^{\circ}\right)$. The angle between the two FGE-derived cysteines and $\mathrm{Cu}(\mathrm{I})$ is significantly smaller than the value $\left(134^{\circ}\right)$ derived from DFT-based modelling based on the structure of scFGE_Cu. ${ }^{27}$ Instead, the much larger $\mathrm{S}_{\mathrm{Cys} 269}-\mathrm{Cu}-\mathrm{S}_{\mathrm{Cys} 1}$ angle opens the triangle enabling two crystallographic waters $\left(\mathrm{H}_{2} \mathrm{O} \_1\right.$, $3.3 \AA ; \mathrm{H}_{2} \mathrm{O} \_2,3.5 \AA$ ) to form near van der Waals contact with $\mathrm{Cu}(\mathrm{I})$. Notably, these two waters are also immobilized by planar trigonal solvation spheres. $\mathrm{H}_{2} \mathrm{O} \_2$ is in contact with $\mathrm{H}_{2} \mathrm{O} \_1$, $\mathrm{H}_{2} \mathrm{O} \_3$ and $\mathrm{H}_{2} \mathrm{O} \_4$ (all $2.8 \AA$ $\mathrm{O}_{3}-\mathrm{O}_{2}-\mathrm{O}_{4}: 119^{\circ}$;). $\mathrm{H}_{2} \mathrm{O} \_1$ also binds to the indole side chain of $\operatorname{Trp} 228(2.9 \AA)$ and Ser266 (2.8 $\AA, \mathrm{O}_{\mathrm{Ser} 266^{-}}-\mathrm{O}_{1}-\mathrm{N}_{\text {Trp228: }}$ : $89^{\circ}$; $\left.\mathrm{N}_{\text {Trp228 }}-\mathrm{O}_{1}-\mathrm{O}_{2}: 129^{\circ} ; \mathrm{O}_{2}-\mathrm{O}_{1}-\mathrm{O}_{\text {Ser266 }}: 140^{\circ}\right)$. In addition, $\mathrm{H}_{2} \mathrm{O} \_1$ and $\mathrm{H}_{2} \mathrm{O} \_2$ make weak contacts with the thiolates of Cys269 (3.1 $\AA)$ and Cys-1 (3.3 ̊̊). This solvation geometry deviates significantly from the more stable tetrahedral solvation spheres 
observed in bulk water, ${ }^{37}$ suggesting that the two crystallographic waters are held in unstable positions. Release of $\mathrm{H}_{2} \mathrm{O}_{-} 1$ and $\mathrm{H}_{2} \mathrm{O} \_2$ from this pocket may provide important enthalpic driving force to enhance $\mathrm{O}_{2}$-binding (see below). ${ }^{38-41}$

Inspection of the next neighbors to Ser266, $\mathrm{H}_{2} \mathrm{O} \_3$ and $\mathrm{H}_{2} \mathrm{O} \_4$ provides information about the position of the protons in this hydrogen-bonding network. In addition to contacting $\mathrm{H}_{2} \mathrm{O} \_1$, the side chain of Ser266 also hydrogen bonds with the backbone amide of Leu268 (3.0 ̊). This interaction suggests that Ser266 is a hydrogen-bond donor with respect to $\mathrm{H}_{2} \mathrm{O}_{-} 1$. $\mathrm{H}_{2} \mathrm{O} \_3$ is in hydrogen-bonding contact with Trp108 (2.9 $⿱$ A) , Trp109 (2.9 $\AA$ ) and the backbone carbonyl of Leu-1 of the substrate (2.7 $\AA$ ). This tetrahedral system suggests that $\mathrm{H}_{2} \mathrm{O} \_3$ is a hydrogen bond donor with respect to $\mathrm{H}_{2} \mathrm{O} \_2$. $\mathrm{H}_{2} \mathrm{O} \_4$ is in contact with the backbone carbonyl of Leu268 (2.8 $\mathrm{\AA}$ ) and is otherwise engulfed by hydrophobic moieties of Phe194, Tyr273 and Cys269. This environment too suggests that $\mathrm{H}_{2} \mathrm{O}_{-} 4$ is a hydrogen bond donor with respect to $\mathrm{H}_{2} \mathrm{O} \_2$. Hence, the pocket that hosts $\mathrm{H}_{2} \mathrm{O} \_1$ and $\mathrm{H}_{2} \mathrm{O} \_2$ in the $t c \mathrm{FGE} \_\mathrm{Cu} \_\mathrm{S}$ structure appears as a highly acidic microenvironment.

Hydrogen bonding to metal-coordinated thiolates are known to affect the nucleophilicity and redox potential of metal-thiolate complexes. ${ }^{\mathbf{4 2 - 4 5}}$ Such interactions are indeed observable in tcFGE_Cu_S. Cys1 makes two weak hydrogen bonds to $\mathrm{H}_{2} \mathrm{O} \_2$ and Arg276, $3.3 \AA$ A, Cys269 hydrogen bonds to $\mathrm{H}_{2} \mathrm{O} \_1$ and the backbone amide of Ser266 (3.3 $\AA$ ), whereas Cys274 only points to the backbone amide of His270 (3.6 $)$. This network may play an important role in stabilizing the high electron density of the tris-thiolate $\mathrm{Cu}(\mathrm{I})$ complex. Incidentally, Cys274 appears as the least stabilized thiolate in the complex suggesting that this residue may be most vulnerable to oxidation during catalysis or as a result of abortive side reactions (see below).

\section{Comparison of $\mathrm{Ag}, \mathrm{Cu}$ and $\mathrm{Cd}-\mathrm{bound} \mathrm{FGE}$ reveals a sequence of coordination changes}

The structure of $t c F G E \_C u \_S$ (resolution: $1.04 \AA$ ) complements the structures of the same enzyme in complex with Ag(I) (resolution: $1.66 \AA$ ) or with Cd(II) (tcFGE_Cd, PDB: 5NYY, resolution: $1.28 \AA$ ). Comparison of the three structures provide a highresolution picture of the structural changes that take place as the coordination sphere expands from linear to trigonal to tetrahedral in order to allow inner-sphere coordination of substrate and $\mathrm{O}_{2}$.

Superposition of the $t c$ FGE_Ag and $t c$ FGE_Cu_S structures highlights three significant changes that are induced by substrate binding. First, the metal center moves by $1.1 \AA$ as it changes from linear to trigonal coordination (Fig. 3). This movement reduces the distance from the metal to $\mathrm{H}_{2} \mathrm{O}_{-} 1$ and $\mathrm{H}_{2} \mathrm{O} \_2$ by about $0.3 \AA$ and $0.8 \AA$ respectively. As a second change, $\mathrm{H}_{2} \mathrm{O} \_1$ and $\mathrm{H}_{2} \mathrm{O} \_2$ are displaced by $0.6 \AA$ from predominantly tetrahedral to purely trigonal planar hydrogen bonding environments. In addition, the interaction partners of $\mathrm{H}_{2} \mathrm{O} \_2$ change. In $t c \mathrm{FGE} \_\mathrm{Ag} \mathrm{H}_{2} \mathrm{O} \_2$ hydrogen bonds with four partners: $\mathrm{H}_{2} \mathrm{O} \_1$ (2.6 ̊) $\mathrm{H}_{2} \mathrm{O} \_50$ (equivalent to $\mathrm{H}_{2} \mathrm{O} \_3,2.8 \AA$ ),

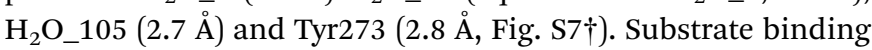
displaces $\mathrm{H}_{2} \mathrm{O} \_105$, leaving $\mathrm{H}_{2} \mathrm{O} \_2$ with only three nearest neighbors in $t c$ FGE_Cu_S. In addition, the side chain of Tyr273 is rotated out of the active site to establish a hydrogen-bond to the backbone amide of Leu- 1 of the substrate. Instead, $\mathrm{H}_{2} \mathrm{O}_{-} 4$ is recruited as third neighbor of $\mathrm{H}_{2} \mathrm{O} \_2$ in $t c \mathrm{FGE} \_\mathrm{Cu} \_\mathrm{S}$. This exchange is likely accompanied with a change in hydrogen bond polarity. In $t c F G E \_A g$ Tyr273 hydrogen bonds with the backbone carbonyl of Leu268 (2.7 $⿱$ A) (Fig. S7 $\dagger$ ), indicating that Tyr273 is a hydrogen bond acceptor with respect to $\mathrm{H}_{2} \mathrm{O} \_2$. In contrast, $\mathrm{H}_{2} \mathrm{O} \_4$ in $t c$ FGE_Cu_S likely acts as a hydrogen bond donor (see above). These changes suggest that substrate binding induces destabilization of $\mathrm{H}_{2} \mathrm{O} \_1$ and $\mathrm{H}_{2} \mathrm{O} \_2$. A third substrate-induced change occurs at Cys274. The dihedral angle along $\mathrm{C} \alpha-\mathrm{C} \beta$ of this residue changed by $58^{\circ}(\mathrm{N} \alpha-\mathrm{C} \alpha-\mathrm{C} \beta-\mathrm{S})$ and the amide function between Cys 274 and Asn 275 rotated by $135^{\circ}$ presumably as a result of the change from linear to trigonal $\mathrm{Cu}(\mathrm{I})$-coordination (Fig. $\mathrm{S} 6 \dagger$ ). A similar rotation was observed in the $t c$ FGE_Cd structure $\left(135^{\circ}\right)$. Hence, this reorganization also seems to be driven by substrate binding.

The structure of $t c$ FGE_Cd provides a model for the enzyme with a tetrahedral coordination site which may be required simultaneous coordination of the substrate and a reactive oxygen species. ${ }^{27}$ Superposition of the structures of $t c$ FGE_Cu_S and $t c$ FGE_Cd shows that the transition from trigonal to tetrahedral coordination moves the metal again by $0.8 \AA$ and reduces the distance between the metal and the position of $\mathrm{H}_{2} \mathrm{O} \_1$ and $\mathrm{H}_{2} \mathrm{O} \_2$ down to $2.8 \AA$ and $2.7 \AA$ (Fig. 3). Tyr273 adopts the same position as in tcFGE_Ag, confirming that the orientation of this residue is dependent on the presence of substrate, rather than on the geometry of the meal complex (Fig. 3). Otherwise, the $t c$ FGE_Cu_S and $t c$ FGE_Cd structures are remarkably similar, suggesting that most active site reorganization that occurs en route from the $\mathrm{Cu}(\mathrm{I})$ resting state to the reactive complex may be induced by substrate-binding.

\section{Trp228 and Ser266 form an anion binding site}

The structure of $t c F G E \_C u \_S$ identifies the position of $\mathrm{H}_{2} \mathrm{O} \_1$ and $\mathrm{H}_{2} \mathrm{O} \_2$ as the only available pocket for $\mathrm{O}_{2}$ to initiate an interaction with the copper center. The opposite face of the trigonal complex is blocked by the side chains of Trp228 and Arg276. Hence, further scrutiny of the subtle changes that occur at this site in response to substrate binding may provide additional insight as to how this unusual metal center can activate $\mathrm{O}_{2}$. The apo structures of $h s$ FGE (PDB: $\left.1 \mathrm{Y} 1 \mathrm{E}\right)^{29}$ and $s c$ FGE (PDB: $2 \mathrm{Q} 17),{ }^{30}$ the metalated forms $t c \mathrm{FGE} \_\mathrm{Ag},{ }^{26} s c \mathrm{FGE} \_\mathrm{Cu},{ }^{27}$ and $t c F G E \_C u \_S$ all contain one crystallographic water $\left(\mathrm{H}_{2} \mathrm{O} \_1\right)$ in hydrogen-bonding distance to Ser266 (2.6-2.8 ̊) and Trp228 (2.9-3.2 A, Fig. S7 $\dagger$ ). In the apo structures the hydrogen bonds with Trp228 are likely weak due to a small bond angle $(\mathrm{N}-\mathrm{H}-\mathrm{O}<$ $130^{\circ}$, Table S4 $\dagger$ ). Nevertheless, several crystal structures of $h s$ FGE with halides bound to the approximate position of $\mathrm{H}_{2} \mathrm{O} \_1$ indicate that this pocket is endowed with significant affinity for anionic species. ${ }^{32,46}$ Most interestingly, addition of metal and substrate to $t c F G E$ increased the bond angle between $\mathrm{H}_{2} \mathrm{O} \_1$ and the indole of Trp228 to $148^{\circ}$ ( $t c \mathrm{FGE} \_\mathrm{Ag}$ ) and $157^{\circ}$ (tcFGE_Cu_S) (Table $\mathrm{S} 4 \dagger)$, suggesting that the presence of metal and substrate also increases bonding interactions at the $\mathrm{O}_{2}$ - 


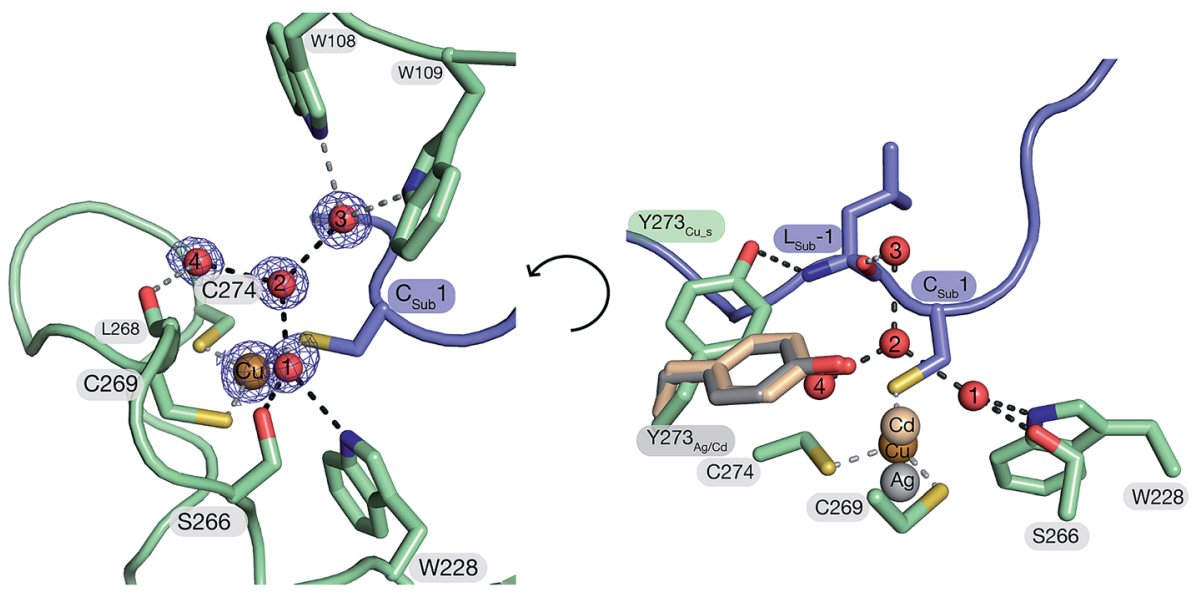

Fig. 3 Left: The primary and secondary coordination sphere of $\mathrm{Cu}(\mathrm{I})$ in the crystal structure of tcFGE_Cu_S (protein: green, substrate: violet). The $2 m\left|F_{\mathrm{o}}\right|-D\left|F_{\mathrm{c}}\right|$ omit map of $\mathrm{Cu}(\mathrm{I})$ and the four crystallographic water molecules $\left(\mathrm{H}_{2} \mathrm{O} \_1-4\right)$ is contoured at $\sigma$-level $=1.0$. Right: Active site of tcFGE_Cu_S including the metals and the side chain of Tyr273 from the structures of tcFGE_Ag (gray) and tcFGE_Cd (beige).

binding site. Also, based on the observed anion-affinity of this pocket we have proposed previously that $\mathrm{H}_{2} \mathrm{O} \_1$ in $t c$ FGE_Ag might be a hydroxide that serves as the base that deprotonates the thiol of the incoming peptidyl cysteine. ${ }^{26}$

\section{Observation of Trp228 by NMR}

To examine the hydrogen bonding interaction between $\mathrm{H}_{2} \mathrm{O}_{-} 1$ and Trp228 in more detail we used NMR spectroscopy. In addition to directly interrogate the chemical environment of specific protons NMR spectroscopy has the key advantage over $\mathrm{X}$-ray measurements (at low temperatures) that the enzyme is examined in solution and at room temperature. ${ }^{1} \mathrm{H}-{ }^{15} \mathrm{~N}$ TROSY HSQC spectra (transverse relaxation-optimized spectroscopy heteronuclear single quantum correlation) were measured using uniformly ${ }^{15} \mathrm{~N}$-labelled $t c$ FGE and $t c \mathrm{FGE}_{\mathrm{W} 228 \mathrm{~F}}$ in apo form and in complex with $\mathrm{Cu}(\mathrm{I})$ on a $600 \mathrm{MHz}$ Bruker NMR instrument. ${ }^{47}$ Superposition of these spectra, in combination with a triple resonance HNCO experiment that distinguishes amidespecific resonances from indole-specific resonances (Fig. S8 and $\mathrm{S} 9 \dagger),{ }^{48}$ allowed unambiguous identification of the $\mathrm{H}^{\varepsilon 1}$ and $\mathrm{N}^{\varepsilon 1}$ signals relating to the indole side chain of Trp228 (Fig. S10$\mathrm{S} 12 \dagger)$. The chemical shifts of indole $\mathrm{H}^{\varepsilon 1}$ and $\mathrm{N}^{\varepsilon 1}$ signals are highly sensitive to their environment, reporting on the solvation of the $\mathrm{N}-\mathrm{H}$ function and the aromatic ring system. ${ }^{49,50}$ Therefore, we reasoned that the Trp288 signal could be used to monitor the protonation state and movements of $\mathrm{H}_{2} \mathrm{O} \_1$. The recorded spectra show that addition of $\mathrm{Cu}(\mathrm{I})$ to apo $t c \mathrm{FGE}$ induced a significant downfield shift of the $\mathrm{H}^{\varepsilon 1}$ signal (Table 1 and Fig. 4). Addition of the substrate to $t c \mathrm{FGE}-\mathrm{Cu}$ induced a further $\mathrm{H}^{\varepsilon 1}$ shift of similar magnitude. Addition of metal also caused slight deshielding of $\mathrm{N}^{\varepsilon 1}$, consistent with increased strength of the hydrogen bond between $\mathrm{H}_{2} \mathrm{O} \_1$ and Trp228. In contrast, addition of substrate caused a marked shielding effect. Inspection of the crystal structures shows, that the indole ring of Trp228 is solvent exposed in tcFGE_Ag and is buried in tcFGE_Cu_S (Fig. S13†). Hence, addition of the substrate reduces the polarity of the medium above the indole ring consistent with the observed shielding effect. The observed deshielding of the indole proton is fully consistent with the proposition that metal and substrate binding increase bonding interactions at the $\mathrm{O}_{2}$-binding site.

Complexation of apo $t c$ FGE with $\mathrm{Ag}$ (I) induced a significantly smaller downfield shift of the $\mathrm{H}^{\varepsilon 1} / \mathrm{N}^{\varepsilon 1}$ signal than observed for $\mathrm{Cu}(\mathrm{I})$ (Table 1 and Fig. 4). A likely cause for this small but significant difference is that the bond angle between the sulfur ligands and the metal is larger for $\mathrm{Ag}(\mathrm{I})$ than for $\mathrm{Cu}(\mathrm{I}) .{ }^{27}$ This slight movement of the metal would push $\mathrm{H}_{2} \mathrm{O} \_1$ closer to Trp228, and therefore strengthen the interaction between the two. The structures of $t c$ FGE_Ag (S-Ag-S: $\left.178^{\circ}\right)$ and $s c$ FGE_Cu $\left(\mathrm{S}-\mathrm{Cu}-\mathrm{S}: 171^{\circ}\right)$ indeed document a small structural difference. ${ }^{27}$ Addition of the substrate to $t c F G E \_A g$ shifted the $\mathrm{H}^{\varepsilon 1} / \mathrm{N}^{\varepsilon 1}$ signal of $t c F G E \_A g \_S$ to exactly the same position as measured with tcFGE_Cu_S (Table 1), suggesting that the two complexes adopt very similar structures. The crystallographic and spectroscopic findings validate $\mathrm{Ag}(\mathrm{I})$ as a reliable structural mimic of $\mathrm{Cu}(\mathrm{I})$ in FGE.

Using this sensitive NMR methodology, we examined the proposition that $\mathrm{H}_{2} \mathrm{O} \_1$ in the $t c \mathrm{FGE} \_\mathrm{Cu}$ is stabilized as a hydroxide. Even though $\mathrm{H}_{2} \mathrm{O}_{-} 1$ is not a metal ligand, it is possible that the proximity of an additional cationic charge, compounded by the interactions with Ser266 and Trp228 could stabilize a hydroxide at physiological $\mathrm{pH}$. Since the $\mathrm{p} K_{\mathrm{a}}$ of water closely matches that of indole rings, a hydrogen bond between indole and hydroxide is likely stronger than between indole and water. Superposition of three ${ }^{1} \mathrm{H}-{ }^{15} \mathrm{~N}$ TROSY HSQC spectra for tcFGE_Cu measured at pH 6, 7 and 8 showed no change of the Trp228 signal relative to other indole-specific resonances (Fig. 4). Based on this observation we concluded that either the $\mathrm{p} K_{\mathrm{a}}$ of $\mathrm{H}_{2} \mathrm{O} \_1$ is far below 6 , or that $\mathrm{H}_{2} \mathrm{O} \_1$ is neutral at physiological $\mathrm{pH}$. The second option is far more likely.

\section{Role of Ser266 and Trp266 in the resting state and in catalysis}

Finally, we examined the effect of the Ser266 to Ala mutation on the interaction of $\mathrm{H}_{2} \mathrm{O} \_1$ with Trp228. ${ }^{1} \mathrm{H}-{ }^{15} \mathrm{~N}$ TROSY HSQC 
Table 1 The observed $\mathrm{H}^{\varepsilon 1}$ and $\mathrm{N}^{\mathrm{e}}$ chemical shifts of Trp228 sidechain upon metalation and substrate binding ${ }^{a}$

\begin{tabular}{|c|c|c|c|c|c|c|c|}
\hline \multirow[b]{2}{*}{ Enzyme } & \multirow[b]{2}{*}{ Metal } & \multicolumn{3}{|c|}{$\delta \mathrm{H}^{\varepsilon 1} / \mathrm{N}^{\mathrm{e} 1} \operatorname{Trp} 228, \mathrm{ppm}$} & \multicolumn{3}{|c|}{$\Delta \delta \mathrm{H}^{\varepsilon 1} / \mathrm{N}^{\mathrm{e} 1}(\operatorname{Trp} 228), \mathrm{ppm}$} \\
\hline & & $\mathrm{E}$ & $\mathrm{E}: \mathrm{M}$ & $\mathrm{E}: \mathrm{M}: \mathrm{S}$ & $\mathrm{E} \rightarrow \mathrm{E}: \mathrm{M}$ & $\mathrm{E}: \mathrm{M} \rightarrow \mathrm{E}: \mathrm{M}: \mathrm{S}$ & $\mathrm{E} \rightarrow \mathrm{E}: \mathrm{M}: \mathrm{S}$ \\
\hline$t c \mathrm{FGE}$ & $\mathrm{Cu}(\mathrm{I})$ & $9.69 / 128.93$ & $9.98 / 130.75$ & $10.22 / 126.66$ & $0.29 / 1.82$ & $0.24 /-4.09$ & $0.53 /-2.27$ \\
\hline$t c \mathrm{FGE}_{\mathrm{S} 266 \mathrm{~A}}$ & $\mathrm{Cu}(\mathrm{I})$ & $9.75 / 129.29$ & $10.04 / 130.78$ & $10.22 / 126.77$ & $0.29 / 1.49$ & $0.18 /-4.01$ & $0.47 /-2.52$ \\
\hline
\end{tabular}

${ }^{a}$ The errors of the given values are estimated to be $<0.02 \mathrm{ppm}$.
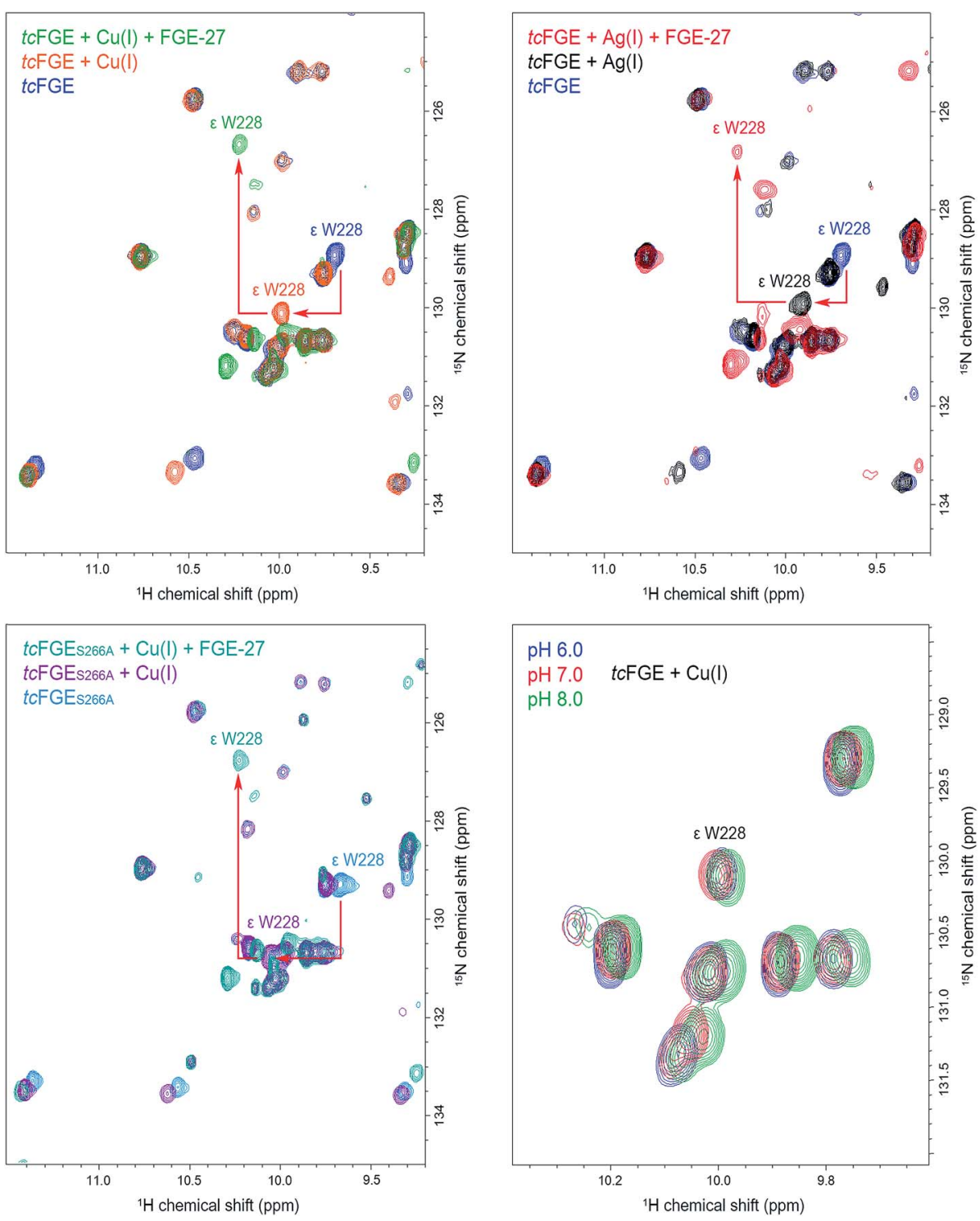

Fig. $4{ }^{1} \mathrm{H}-{ }^{15} \mathrm{~N}$ TROSY HSQC spectra of uniformly ${ }^{15} \mathrm{~N}$-labelled $300 \mu \mathrm{M}$ tcFGE in $20 \mathrm{mM}$ phosphate buffer, $50 \mathrm{mM} \mathrm{NaCl}, 2 \mathrm{mM}$ DTT, $25 \mathrm{C}$. The downfield area of the amide region is presented. Top left: The overlay of the spectra of apo-form tcFGE, pH 8.0 (dark blue), tcFGE in the presence of $450 \mu \mathrm{M} \mathrm{CuSO}_{4}, \mathrm{pH} 8.0$ (orange), tcFGE in the presence of $450 \mu \mathrm{M} \mathrm{CuSO}_{4}$ and $1 \mathrm{mM} \mathrm{FGE-27,} 2 \mathrm{mM}$ glucose, 2 units (U) glucose oxidase (GO), $200 \mathrm{U}$ catalase (CAT), pH 8.1 (green). Top right: The overlay of the spectra of apo-form tcFGE, pH 8.0 (dark blue), tcFGE in the presence of $450 \mu M$ $\mathrm{AgNO}_{3}, \mathrm{pH} 8.0$ (black), tcFGE in the presence of $450 \mu \mathrm{M} \mathrm{AgNO}$ and $1 \mathrm{mM}$ FGE-27, 2 mM glucose, $2 \mathrm{U}$ GO, $200 \mathrm{U}$ CAT, pH 8.1 (red). Bottom left:

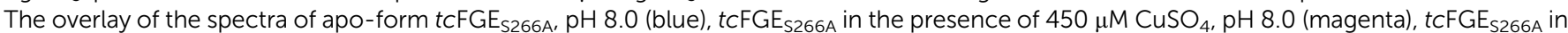
the presence of $450 \mu \mathrm{M} \mathrm{CuSO}_{4}$ and $1 \mathrm{mM} \mathrm{FGE-27,2} \mathrm{mM}$ glucose, $2 \mathrm{U}$ GO, $200 \mathrm{U}$ CAT, pH 8.1 (dark cyan). Bottom right: The overlay of the spectra tcFGE in the presence of $450 \mu \mathrm{M} \mathrm{CuSO}_{4}$ measured at different $\mathrm{pH}$. 


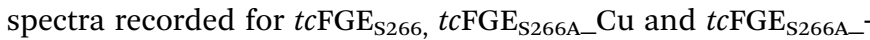
$\mathrm{Cu} \_\mathrm{S}$ revealed only small or no deshielding effects on the $\mathrm{H}^{\varepsilon 1}$ / $\mathrm{N}^{\varepsilon 1}$ signal, suggesting that the absence of the Ser266 side chain does not affect the interaction between $\mathrm{H}_{2} \mathrm{O} \_1$ and Trp228. Hence, the role of Ser266 in immobilizing $\mathrm{H}_{2} \mathrm{O}_{-} 1$ in the tcFGE_Cu_S complex is limited. In stark contrast, the same mutation causes a 50 -fold reduction in catalytic turnover $\left(k_{\text {cat }}\right)$ without affecting substrate binding $\left(K_{\mathrm{m}}\right.$, Table 2$) .{ }^{25}$ The kinetic and spectroscopic properties of $t c \mathrm{FGE}_{\mathrm{S} 266 \mathrm{~A}}$ suggest that Ser266 provides a hydrogen bond that become important after substrate-binding. Similarly, mutation of Trp228 to Phe $\left(t c \mathrm{FGE}_{\mathrm{W} 288 \mathrm{~F}}\right)$ also specifically affects $k_{\text {cat }}$ without hurting substrate binding. The lack of this hydrogen bond donor in the $\mathrm{O}_{2}$-binding site is likely to contribute to the demise of catalysis by this variant.

\section{The unusual resting state of FGE}

The active site of FGE is unusual for several reasons. First, catalysts that use a bis-cysteine coordinated $\mathrm{Cu}(\mathrm{I})$ as a starting point for $\mathrm{O}_{2}$-dependent $\mathrm{C}-\mathrm{H}$ cleavage is unexplored territory. A large number of studies have shown quite conclusively that imidazole, amine, amide and thioether ligands are particularly well suited to facilitate copper-mediated $\mathrm{O}_{2}$-activation, not the least because these ligands stabilize high-valent copper species. ${ }^{\mathbf{1 - 3 , 5 1 , 5 2}}$ From this perspective, bis- or tris-thiolate coordination spheres seem odd choices for designing copperdependent oxidation catalysts. Thiolate ligands stabilize $\mathrm{Cu}(\mathrm{I})$ which should render electron transfer to $\mathrm{O}_{2}$ more difficult. On the other hand, thiolates are intrinsically vulnerable to oxidation which may open efficient paths for catalyst destruction. A specific complication of the FGE-catalyzed reaction is that the two active site cysteines and the substrate contain altogether six chemically equivalent cysteinyl $\mathrm{C}_{\beta}-\mathrm{H}$ bonds. Hence, the geometry of the active site must ensure that the reactive oxygen species exclusively attacks the pro- $(R)-\beta$-hydrogen on the substrate. ${ }^{19}$ The structure of $t c F G E \_C u \_S$ visualizes how the enzyme achieves regiospecificity. All three cysteines approach $\mathrm{Cu}(\mathrm{I})$ in a similar angle (C $\left.\beta-\mathrm{S}-\mathrm{Cu}: 103-120^{\circ}\right)$ and place their $\mathrm{C} \beta$ at a similar distance to the copper center (3.2-3.5 $\AA$ ). However, only the pro- $(R)-\beta$-hydrogen of the substrate points towards the presumed $\mathrm{O}_{2}$-binding site (Fig. 5).

The second unusual feature of FGE is that the substrate and the reactive oxygen species both coordinate to the metal. ${ }^{1,27}$ Metaldependent oxidases often bind $\mathrm{O}_{2}$ via displacement of a weakly bound metal ligand, such as water, at a pre-formed coordination

Table 2 The Characterization of the catalytic activity of tcFGE variants using HPLC-based kinetic assay ${ }^{a}$

\begin{tabular}{lclc}
\hline Enzyme & $k_{\text {cat }},\left[\mathrm{min}^{-1}\right]$ & $K_{\mathrm{m}},[\mu \mathrm{M}]$ & $k_{\text {cat }} / K_{\mathrm{m}},\left[\mathrm{min}^{-1} \mathrm{M}^{-1}\right]$ \\
\hline$t c \mathrm{FGE}$ & $1.4 \pm 0.07$ & $530 \pm 40$ & $2700 \pm 200$ \\
$t c \mathrm{FGE}_{\mathrm{S} 266 \mathrm{~A}}{ }^{b}$ & $0.025 \pm 0.002$ & $520 \pm 240$ & $49 \pm 8$ \\
$t c \mathrm{FGE}_{\mathrm{W} 228 \mathrm{~F}}$ & $0.0073 \pm 0.0002$ & $390 \pm 20$ & $19 \pm 1$
\end{tabular}

${ }^{a}$ Kinetic parameters were determined in the presence of $2 \mu \mathrm{M} \mathrm{CuSO}_{4}$, $5 \mathrm{mM}$ DTT, $50 \mathrm{mM} \mathrm{NaCl}$ and $50 \mathrm{mM}$ Tris buffer $\mathrm{pH} 8.0$, at 25C. Rate determined by monitoring the formation of fGly. ${ }^{b}$ From ref. 25.

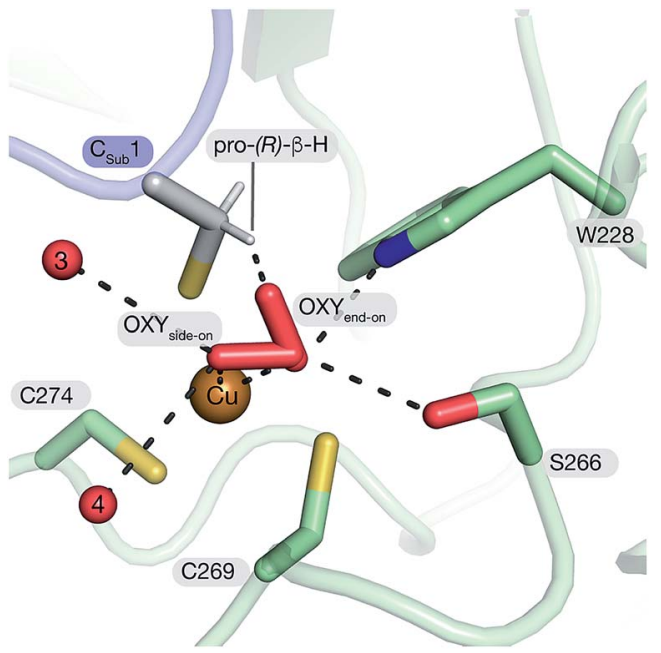

Fig. 5 Structure-based model of tcFGE_Cu_S with superoxide coordinated to $\mathrm{Cu}(\|)$ in side-on mode $\left(\eta^{1}\right)$ or end-on mode $\left(\eta^{2}\right)$.

site. Formation of the coordination bond is accompanied by reduction of $\mathrm{O}_{2}$ to superoxide via inner-sphere electron transfer. For example, PHM coordinates Cu(I) via the side chains of two histidines and one methionine in a near tetrahedral geometry. The fourth ligand is a water molecule that is displaced by $\mathrm{O}_{2} \cdot{ }^{9,10} \mathrm{In}$ LPMO Cu(I) is coordinated by a histidine brace $(\mathrm{N} \alpha / \mathrm{N} \pi)$ and the side chain of a second histidine. ${ }^{7}$ The square planar coordination sphere is completed by a chloride or a water molecule filling the dedicated $\mathrm{O}_{2}$ binding site. CAO coordinates copper with three histidines and a loosely bound water. Displacement by $\mathrm{O}_{2}$ occurs without change in the coordination geometry. ${ }^{11}$ We note that the path leading to the cupric superoxide in CAO is controversial. In the conventional mechanism $\mathrm{O}_{2}$ forms a coordination bond with $\mathrm{Cu}(\mathrm{I}) \cdot{ }^{53}$ An alternative proposal suggests that prebound $\mathrm{O}_{2}$ is first reduced by a protein-derived redox cofactor, and then combines as superoxide with $\mathrm{Cu}(\mathrm{II}){ }^{54}$

In contrast to these enzymes, the substrate complex of $t c \mathrm{FGE}$ contains no preformed coordination site for a fourth ligand. The tris-thiolate $\mathrm{Cu}(\mathrm{I})$ complex is completely planar and the closest crystallographic waters $\left(\mathrm{H}_{2} \mathrm{O} \_1\right.$ and $\left.\mathrm{H}_{2} \mathrm{O} \_2\right)$ are too distant for attractive interactions. Hence, direct binding of $\mathrm{O}_{2}$ would require a change in coordination geometry. The structure of $t c$ FGE in complex with $\mathrm{Cd}$ (II) showed a tetrahedral coordination sphere around this bivalent metal. Therefore it is plausible that oxidation of $\mathrm{Cu}(\mathrm{I})$ to $\mathrm{Cu}$ (II) may trigger a change from trigonal planar to tetrahedral coordination. ${ }^{26}$ Importantly, if $\mathrm{O}_{2}$ coordination requires structural change, and this change requires oxidation of $\mathrm{Cu}(\mathrm{I})$, it is unlikely that this redox reaction occurs via inner-sphere electron transfer as in other mononuclear copper enzymes. A more plausible scenario is that $\mathrm{O}_{2}$ first binds to the active site without direct contact to the metal (C, Fig. 6). Outer sphere electron transfer from $\mathrm{Cu}(\mathrm{I})$ to prebound $\mathrm{O}_{2}$ followed by coordination would produce the predicted cupric superoxide complex (D). The efficiency of outer sphere electron transfer would critically rely on a binding site that increases the redox potential of pre-bound $\mathrm{O}_{2}$. 

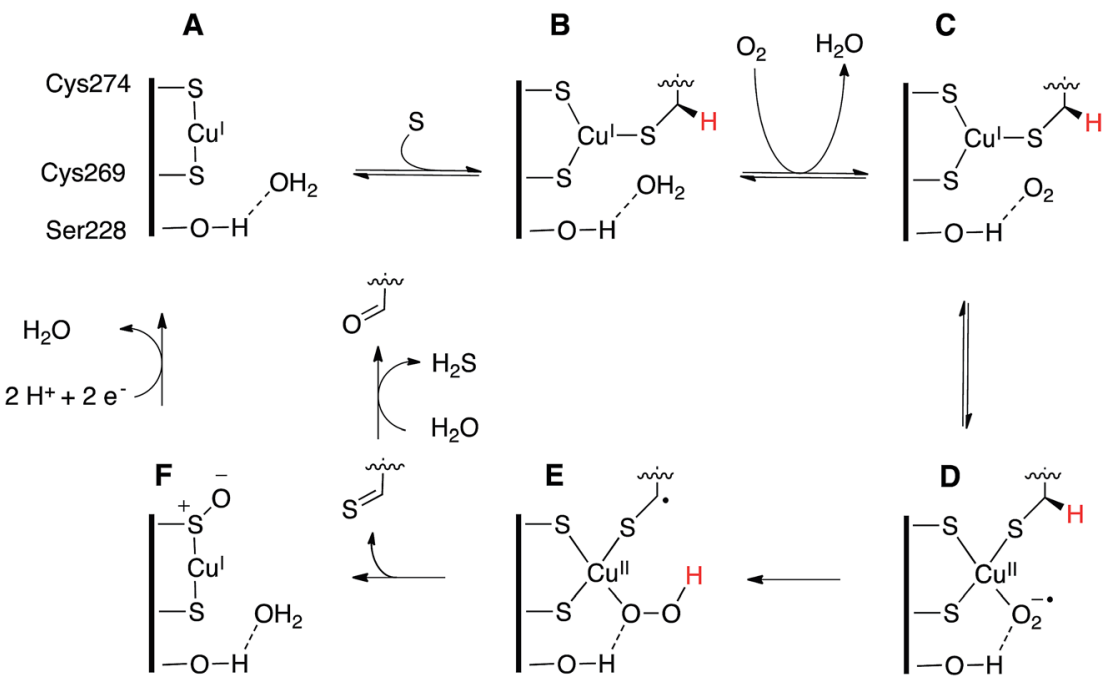

Fig. 6 Proposed catalytic mechanism of FGE. The reaction starts with sequential binding of substrate and $\mathrm{O}_{2}$ forming first complex B (crystallized) and then $\mathrm{C}$. Outer sphere electron transfer from $\mathrm{Cu}(\mathrm{I})$ to $\mathrm{O}_{2}$ could produce the $\mathrm{Cu}(\mathrm{II})$ superoxide species D (modelled in Fig. 5). Homolytic abstraction of the pro- $(R)-\beta$-hydrogen atom from the substrate $(\mathrm{E})$, followed by release and hydrolysis of the oxidized peptide product and reduction of the oxidized enzyme form (F) return the enzyme to the catalytically active resting state $A$.

This requirement highlights the third unusual feature of FGE. The presumed $\mathrm{O}_{2}$-binding site in $t c \mathrm{FGE}$ is lined with an extensive array of hydrogen bond donors. Hydrogen-bonding has been recognized as important modulator of the stability and reactivity of copper-coordinated oxygen species in enzymes and in abiotic catalysts. ${ }^{1,2,55-57}$ For example, hydrogen-bonding to the proximal oxygen atom of a synthetic cupric superoxide complex has been shown to increase its stability and its propensity for hydrogen atom abstraction in direct correlation with hydrogen-bonding strength. ${ }^{55}$ Furthermore, specific hydrogen-bonding to the distal or to the proximal oxygen has been shown to affect the activity of copper-oxygen adducts in very different ways. $^{56}$ On the other hand, oxygen-binding pockets lined by four well-positioned hydrogen bond donors are rare among metal-dependent catalysts. Studies on synthetic cages showed that solvation of $\mathrm{O}_{2}$ with multiple amide- or amine-donated hydrogen bonds can significantly stabilize superoxide and peroxide anions. ${ }^{58,59}$ The acidic $\mathrm{O}_{2}$-binding pocket in FGE may play a similar stabilizing role and thereby facilitate electron transfer from the electron-rich tris-thiolate $\mathrm{Cu}(\mathrm{I})$ to $\mathrm{O}_{2}$. The observation that mutation of Ser266 or Trp228 dramatically reduce the activity of $t c$ FGE is consistent with this interpretation.

\section{Conclusions}

In this report we describe the crystal structure of $t c \mathrm{FGE}$ in complex with $\mathrm{Cu}(\mathrm{I})$ and a 17-residue peptide. Comparisons of this complex with the structures of $t c$ FGE bound to $\mathrm{Ag}$ (I) or $\mathrm{Cd}$ (II) highlight substrate-induced changes that may prime the active site for $\mathrm{O}_{2}$-binding. On the other hand, we also found that substrate binding does not induce a preformed coordination site for $\mathrm{O}_{2}$ at the metal center. These observations raise the possibility that FGE activates $\mathrm{O}_{2}$ in a different way than other metallo-enzymes. Specifically, we propose that $\mathrm{O}_{2}$ first extracts an electron from $\mathrm{Cu}(\mathrm{I})$ via outer sphere electron transfer before combining to a cupric superoxide species. This and other testable hypotheses emanating from our structural investigating set the stage for deciphering the detailed mechanism of this unusual oxidation catalyst. We also hope to inspire the synthesis and characterization of abiotic catalysts that exploit this reactivity of bis- and tris-thiolate coordinated copper species.

\section{Conflicts of interest}

There are no conflicts to declare.

\section{Acknowledgements}

We thank Prof. Dr Oliver Einsle (Univ. Freiburg) for the access to the equipment used for anaerobic crystallization, the Swiss Lightsource (Villigen, Switzerland) for access to the beamline facilities and beamline staff for support. This project was supported by a starting grant from the European Research Council (ERC-2013-StG 336559), the NCCR for Molecular Systems Engineering and by the "Professur für Molekulare Bionik".

\section{References}

1 E. I. Solomon, D. E. Heppner, E. M. Johnston, J. W. Ginsbach, J. Cirera, M. Qayyum, M. T. Kieber-Emmons, C. H. Kjaergaard, R. G. Hadt and L. Tian, Chem. Rev., 2014, 114, 3659-3853.

2 C. E. Elwell, N. L. Gagnon, B. D. Neisen, D. Dhar, A. D. Spaeth, G. M. Yee and W. B. Tolman, Chem. Rev., 2017, 117, 2059-2107. 
3 W. Keown, J. B. Gary and T. D. Stack, J. Biol. Chem., 2017, 22, 289-305.

4 S. E. Allen, R. R. Walvoord, R. Padilla-Salinas and M. C. Kozlowski, Chem. Rev., 2013, 113, 6234-6458.

5 J. T. Rubino and K. J. Franz, J. Inorg. Biochem., 2012, 107, 129-143.

6 R. J. Quinlan, M. D. Sweeney, L. L. Leggio, H. Otten, J. C. N. Poulsen, K. S. Johansen, K. B. R. M. Krogh, C. I. Jorgensen, M. Tovborg, A. Anthonsen, T. Tryfona, C. P. Walter, P. Dupree, F. Xu, G. J. Davies and P. H. Walton, Proc. Natl. Acad. Sci. U. S. A., 2011, 108, 15079-15084.

7 K. E. Frandsen, T. J. Simmons, P. Dupree, J. C. Poulsen, G. R. Hemsworth, L. Ciano, E. M. Johnston, M. Tovborg, K. S. Johansen, P. von Freiesleben, L. Marmuse, S. Fort, S. Cottaz, H. Driguez, B. Henrissat, N. Lenfant, F. Tuna, A. Baldansuren, G. J. Davies, L. Lo Leggio and P. H. Walton, Nat. Chem. Biol., 2016, 12, 298-303.

8 L. Cao, O. Caldararu, A. C. Rosenzweig and U. Ryde, Angew. Chem., Int. Ed., 2018, 57, 162-166.

9 S. T. Prigge, B. A. Eipper, R. E. Mains and L. M. MAmzel, Science, 2004, 304, 864-867.

10 S. T. Prigge, A. S. Kolhekar, B. A. Eipper, R. E. Mains and M. Amzel, Nat. Struct. Biol., 1999, 6, 976-983.

11 C. M. Wilmot, J. Hajdu, M. J. McPherson, P. F. Knowles and S. E. Phillips, Science, 1999, 286, 1724-1728.

12 T. V. Vendelboe, P. Harris, Y. Zhao, T. S. Walter, K. Harlos, K. El Omari and H. E. M. Christensen, Sci. Adv., 2016, 2, e1500980.

13 J. Y. Lee and K. D. Karlin, Curr. Opin. Chem. Biol., 2015, 25, 184-193.

14 A. Changela, K. Chen, Y. Xue, J. Holschen, C. E. Outten, T. V. OHalloran and A. Mondragon, Science, 2003, 301, 1383-1387.

15 A. K. Wernimont, D. L. Huffman, A. L. Lamb, T. V. OHalloran and A. C. Rosenzweig, Nat. Struct. Biol., 2000, 7, 766-771.

16 A. K. Boal and A. C. Rosenzweig, Chem. Rev., 2009, 109, 47604779.

17 L. Banci, I. Bertini, F. Cantini, I. C. Felli, L. Gonnelli, N. Hadjiliadis, R. Pierattelli, A. Rosato and P. Voulgaris, Nat. Chem. Biol., 2006, 2, 367-368.

18 P. G. Holder, L. C. Jones, P. M. Drake, R. M. Barfield, S. Banas, G. W. de Hart, J. Baker and D. Rabuka, J. Biol. Chem., 2015, 290, 15730-15745.

19 M. Knop, P. Engi, R. Lemnaru and F. P. Seebeck, ChemBioChem, 2015, 16, 2147-2150.

20 T. Dierks, B. Schmidt, L. V. Borissenko, J. H. Peng, A. Preusser, M. Mariappan and K. von Figura, Cell, 2003, 113, 435-444.

21 M. P. Cosma, S. Pepe, I. Annunziata, R. F. Newbold, M. Grompe, G. Parenti and A. Ballabio, Cell, 2003, 113, 445-456.

22 I. S. Carrico, B. L. Carlson and C. R. Bertozzi, Nat. Chem. Biol., 2007, 3, 321-322.

23 M. J. Appel and C. R. Bertozzi, ACS Chem. Biol., 2015, 10, 72-84.

24 T. Krüger, T. Dierks and N. Sewald, Biol. Chem., 2019, 4000, 289-297.
25 M. Knop, T. Q. Dang, G. Jeschke and F. P. Seebeck, ChemBioChem, 2017, 18, 161-165.

26 M. Meury, M. Knop and F. P. Seebeck, Angew. Chem., Int. Ed., 2017, 56, 8115-8119.

27 M. J. Appel, K. K. Meier, J. Lafrance-Vanasse, H. Lim, C. L. Tsai, B. Hedman, K. O. Hodgson, J. A. Tainer, E. I. Solomon and C. R. Bertozzi, Proc. Natl. Acad. Sci. U. S. A., 2019, 116(12), 5370-5375.

28 M. Jaskolski, M. Gilski, Z. Dauter and A. Wlodawer, Acta Crystallogr., Sect. D: Biol. Crystallogr., 2007, 63, 611-620.

29 T. Dierks, A. Dickmanns, A. Preusser-Kunze, B. Schmidt, M. Mariappan, K. von Figura, R. Ficner and M. G. Rudolph, Cell, 2005, 121, 541-552.

30 B. L. Carlson, E. R. Ballister, E. Skordalakes, D. S. King, M. A. Breidenbach, S. A. Gilmore, J. M. Berger and C. R. Bertozzi, J. Biol. Chem., 2008, 283, 20117-20125.

31 A. J. Doig, M. W. MacArthur, B. J. Stapley and J. M. Thornton, Protein Sci., 1997, 6, 147-155.

32 D. Roeser, A. Preusser-Kunze, B. Schmidt, K. Gasow, J. G. Wittmann, T. Dierks, K. von Figura and M. G. Rudolph, Proc. Natl. Acad. Sci. U. S. A., 2006, 103, 8186.

33 M. Knop, R. Lemnaru and F. P. Seebeck, ChemBioChem, 2017, 18, 1755-1761.

34 E. L. Smith, J. P. Giddens, A. T. Iavarone, K. Godula, L. X. Wang and C. R. Bertozzi, Bioconjugate Chem., 2014, 25, 788-795.

35 J. H. Peng, S. Alam, K. Radhakrishnan, M. Mariappan, M. G. Rudolph, C. May, T. Dierks, K. von Figura and B. Schmidt, FEBS J., 2015, 282, 3262-3274.

36 T. Krüger, S. Weiland, G. Falck, M. Gerlach, M. Boschanski, S. Alam, K. M. Müller, T. Dierks and N. Sewald, Angew. Chem., Int. Ed., 2018, 57, 7245-7249.

37 T. Urbic and K. A. Dill, J. Am. Chem. Soc., 2018, 140, 1710617113.

38 A. Biela, N. N. Nasief, M. Betz, A. Heine, D. Hangauer and G. Klebe, Angew. Chem., Int. Ed., 2013, 52, 1822-1828.

39 M. C. Chervenak and E. J. Toone, J. Am. Chem. Soc., 1994, 116, 10533-10539.

40 P. W. Snyder, J. Mecinovic, D. T. Moustakas, S. W. r. Thomas, M. Harder, E. T. Mack, M. R. Lockett, A. Héroux, W. Sherman and G. M. Whitesides, Proc. Natl. Acad. Sci. U. S. A., 2011, 108, 17889-17894.

41 F. Biedermann, W. M. Nau and H. J. Schneider, Angew. Chem., Int. Ed., 2014, 53, 11158-11171.

42 P. C. Roehm and J. M. Berg, J. Am. Chem. Soc., 1998, 120, 13083-13087.

43 S. J. Chiou, C. G. Riordan and A. L. Rheingold, Proc. Natl. Acad. Sci. U. S. A., 2003, 1000, 3695-3700.

44 A. Dey, T. A. Okamura, N. Ueyama, B. Hedman, K. O. Hodgson and E. I. Solomon, J. Am. Chem. Soc., 2005, 127, 12046-12053.

45 X. Yang, S. Niu, T. Ichiye and L. S. Wang, J. Am. Chem. Soc., 2004, 126, 15790-15794.

46 D. Roeser, B. Schmidt, A. Preusser-Kunze and M. G. Rudolph, Acta Crystallogr., Sect. D: Biol. Crystallogr., 2007, 63, 621-627. 
47 K. Pervushin, R. Riek, G. Wider and K. Wüthrich, Proc. Natl. Acad. Sci. U. S. A., 1997, 94, 12366-12371.

48 S. Grzesiek and A. Bax, J. Magn. Reson., 1992, 96, 432-440.

49 W. Sicinska, W. M. Westler and H. F. DeLuca, Proteins, 2005, 61, 461-467.

50 E. T. Mollova, D. E. Metzler, A. Kintanar, H. Kagamiyama, H. Hayashi, K. Hirotsu and I. Miyahara, Biochemistry, 1997, 36, 615-625.

51 S. M. Adam, G. B. Wijeratne, P. J. Rogler, D. E. Diaz, D. A. Quist, J. J. Liu and K. D. Karlin, Chem. Rev., 2018, 118, 10840-11022.

52 L. Ciano, G. J. Davies, W. B. Tolman and P. H. Walton, Nat. Catal., 2018, 1, 571-577.

53 E. M. Shepard, K. M. Okonski and D. M. Dooley, Biochemistry, 2008, 47, 13907-13920.
54 S. A. Mills, Y. Goto, Q. Su, J. Plastino and J. P. Klinman, Biochemistry, 2002, 41, 10577-10584.

55 M. Bhadra, J. Y. C. Lee, R. E. Cowley, S. Kim, M. A. Siegler, E. I. Solomon and K. D. Karlin, J. Am. Chem. Soc., 2018, 140, 9042-9045.

56 S. I. Mann, T. Heinisch, T. R. Ward and A. S. Borovik, J. Am. Chem. Soc., 2017, 139, 17289-17292.

57 S. Hong, Y.-M. Lee, K. Ray and W. Nam, Coord. Chem. Rev., 2017, 334, 25-42.

58 N. Lopez, D. J. Graham, R. J. McGuire, G. E. Alliger, Y. ShaoHorn, C. C. Cummins and D. G. Nocera, Science, 2012, 335, 450-453.

59 E. W. Dahl, J. J. Kiernicki, M. Zeller and N. K. Szymczak, J. Am. Chem. Soc., 2018, 140, 10075-10079. 